\title{
PALAEOECOLOGY OF THE NEOTROPICS: AN OVERVIEW OF THE STATE OF AFFAIRS
}

T.van der Hammen ${ }^{1}$

\section{ABSTRACT}

An overview is given of the most important data on the palaeoecology of the Neotropics, with special emphasis on the Quaternary. Strong changes of temperature and rainfall affected tropical South (and Middle) America during the last few million of years. These changes are known in more detail from the last glacial-interglacial cycle. Relatively humid and cooler climates occurred in the period between $>50,000$ and ca.25,000/30,000 years B.P.A cold and very dry climate occurred in the period of ca.21,000-c.14,000 B.P. Between 13,000 and 10,000 B.P. the climate became warmer and more humid, and from 10,000 B.P. to the present (the Holocene), the climate is more like the present, but there are still changes of temperature and especially of rainfall. While quantitative data of changes of temperature could be established beyond reasonable doubt in the high tropical Andes $\left(6^{\circ} \mathrm{C}-9^{\circ} \mathrm{C}\right)$, ciphers for the tropical lowland are still uncertain (they might have been $2^{\circ}$ to $6^{\circ}$ lower than today).

There is no doubt that the rainforest disappeared and was replaced by savanna or semidesert in some areas during certain climatic intervals. This was relatively well established on several sites in the southern part of the Amazon basin, in Bolivia and Brazil. In the northern savanna area of South America, large areas were changed in sand deserts.

\section{INTRODUCTION}

The forests of the neotropics comprise, besides the tropical rainforest, many other types,

\footnotetext{
${ }^{1}$ Hugo de Vries Laboratorium, University of Amsterdam, the Netherlands.
} 
corresponding partly to progressively drier climates (in annual rainfall and/or number of dry months), and partly to progressively colder tropical mountain climates (in average annual temperature, the seasonal thermal differences being only slight). Hence there is not only tropical rainforest, but also savanna woodland, high montane forest, etc. Geographically this differentiation corresponds very roughly with the Amazon basin, a savanna and savanna woodland or cerrado zone north and south of the basin, and the Andes as a North-South wall west of the basin. To this general picture we may add the presence of rainforest west of the northern Andes, and in deep larger longitudinal valleys in the Andes (like resp. the Choco area and the middle and northern Magdalena valley), the "atlantic rainforest" of Brazil, etc.

The headwaters of the Amazon are on the eastern slopes of the Andes, draining generally speaking the eastern half of the Andes; they are white water rivers, transporting abundantly clayey sediments; part of the afluents, however, are Amazonian rivers, having their origin e.g. in the Guyana shield area like the Rio Negro; they are black water rivers, almost devoid of clayey sediment load.

The Orinoco originates also partly on the eastern slopes of the Northern Andes, partly in the rainforest area and passes through the northern savanna and savanna woodland area (Uanos Orientales of Colombia and Orinoco savannas of Venezuela). The Magdalena river with its afluents, the Cauca and San Jorge rivers, has its headwaters in all the three main chains (Cordilheira Occidental, Central and Oriental) of the northern Andes, draining most of this area, with the exception of the east flank of the Cordillera Oriental (being part of the Orinoco and Amazon watersheds) and the west flank of the Cordillera Occidental (Rio Atrato watershed and rivers going to the Pacific). In this way a very large proportion of the rain falling on the continent is being transported towards the Atlantic side (Caribbean and Atlantic ocean) and a very small proportion towards the Pacific ocean.

Rainfall in the Amazon basin and other forested lowlands in northern South America is not homogeneous (Fig. 1). Annual rainfall is relatively high in a zone broadly along the northwestern coast (up to $>3,000 \mathrm{~mm}$ ). South of this line is a drier belt passing NW-SE through the Amazon basin, with rainfalls locally $<1,500 \mathrm{~mm}$. South and west of this belt rainfall is higher again, reaching values above $3,000 \mathrm{~mm}$ in a broad zone, and even higher values against the eastern slopes of the Andes. Extremely high rainfall (locally even up to $10,000 \mathrm{~mm}$ and more) is found on the western side of the West Cordillera, in the Chocó area. Annual rainfall decreases and the numbers of dry months with water deficit increases southward and southeastward and northward of the rainforest area, where savanna woodland and savanna vegetation is taking over. Extremely low rainfalls like along part of the northwestern Caribbean coast and along the Pacific coast of Peru, lead to the total disappearance of forest.

In the Andes rainfalls are highest on the outer slopes of the Cordilleras, but especially on the eastern slope of the Cordillera Oriental and the western slope of the Cordillera Occidental. Low annual rainfall ciphers are found in longitudinal (N-S) relatively narrow interandean valleys and other areas in "rain shadow". Average annual temperatures in the tropical Andes go from $25-30^{\circ} \mathrm{C}$ in the lowlands at the foot of 


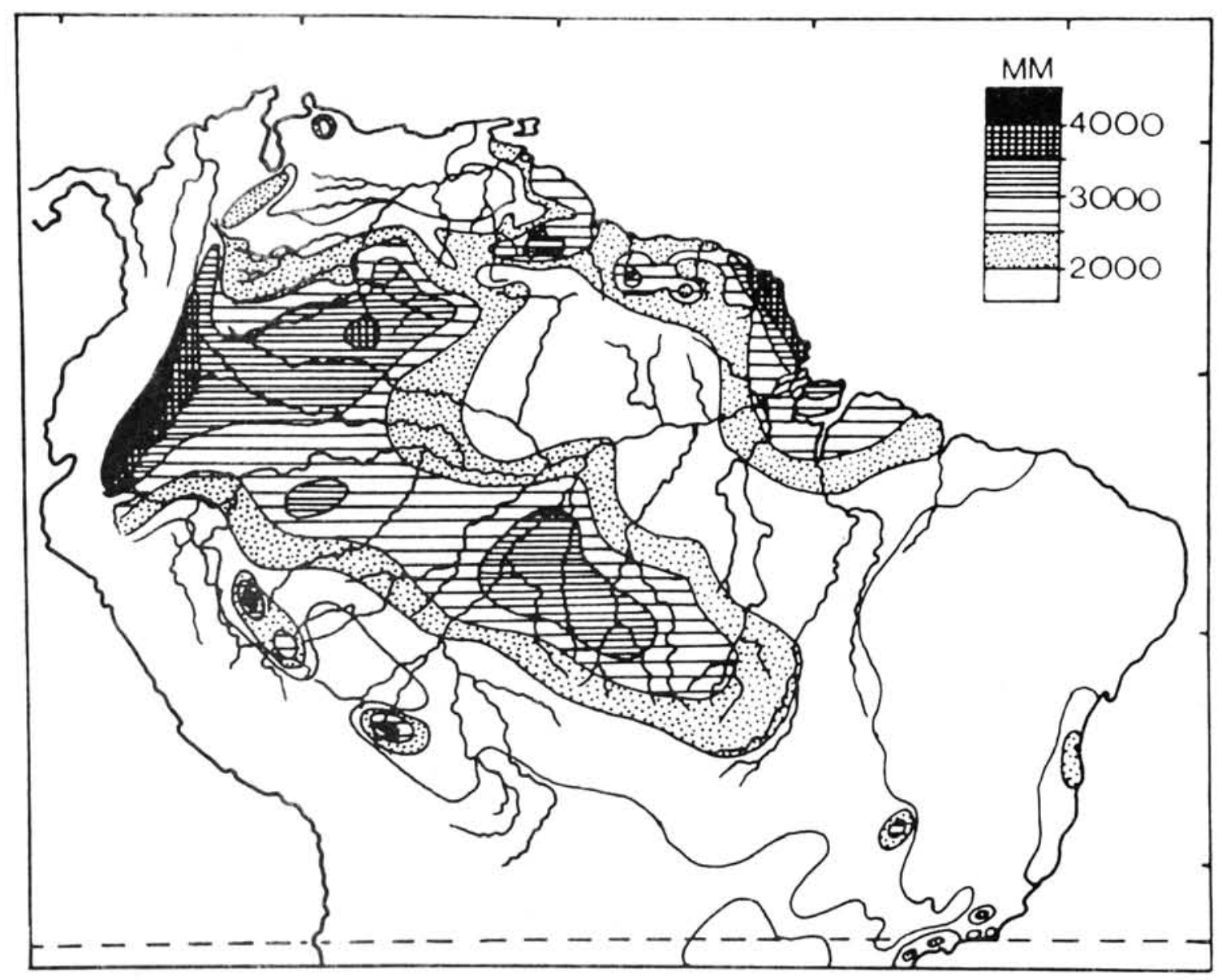

Figure 1 - Present day precipitation for the area east of the Andes (after SIMPSON \& HAFFER, 1978).

the mountains to below $0^{\circ} \mathrm{C}$ above $5,000 \mathrm{~m}$. The upper limit of the closed higher forest lies between 3,000 and $4,000 \mathrm{~m}$, but mostly between 3,300 and $3,800 \mathrm{~m}$; differences in rainfall and exposition towards the lowlands seem to have influence on the exact position of the forest limit between these extremes. In the Central Cordillera, the altitudinal forest limit corresponds to an average annual temperature of slightly above $6^{\circ} \mathrm{C}$, in the Santa Marta mountains to slightly above $7^{\circ} \mathrm{C}$ (NAN DER HAMMEN et al., 1983; VAN DER HAMMEN \& RUIZ, 1984). Isolated patches of high Andean forest may, however, be found up to more than $4,200 \mathrm{~m}$.

The Neotropical flora is extremely rich in species, broadly speaking twice as much as the paleotropical floras. This richness of species, especially of the forest vegetation, but also that of the savannas and high open Andean vegetations (the páramo and the puna), is intimately related to the prePleistocene geological history of the area (and a closely related climate history), that we will discuss very 
shortly. It is, however, from the Quaternary history (Pleistocene and Holocene) that we have obtained information on the dynamic relation of climate and vegetation, which is of considerable importance for an evaluation by extrapolation of the possible future natural and man-induced changes.

\section{PRE-PLEISTOCENE HISTORY}

The history of the Neotropical flora goes back to the Jurassic Gondwanaland, consisting of the present-day South America, Africa, Antarctica, Australia and India. South America and Africa lay close together and the Middle Cretaceous floras found in West Africa and South America are so similar, that one may consider them to represent one and the same floristic province, very different from other parts of the world. The climate in the central part of that large continent, seems to have been relatively dry. The first angiosperms appear in that time. In the late Cretaceous, and especially in the beginning of the Tertiary, there are still rather clear floristic relations between Africa and South America, but at the same time we see the beginning of a development that will lead to the proper present-day Neotropical flora. Such important groups as the Mauritieae (Palms) and the Bombacaceae and mangrove-forests of a species known as Proxapertites appear near the Cretaceous-Tertiary boundary. During the Eocene this mangrove species in replaced by another known only by its pollen: Retibrevitricolpites, and finally (in the upper Eocene and Oligocene) the present-day mangrove genus Rhizophora appears and will play an important part in the coastal mangroves up to the present day. Equally in the Eocene appear families like the Malpighiaceae, and such an important genus as Alchornea. The formation of bauxites known from different places, seems to indicate a warm and wet tropical climate. During the Oligocene and especially the Miocene we have already a tropical lowland flora, that resembles considerably the actual lowland vegetation while extensive lowland marshes with peat formation exist, both in the lowlands of the present-day northern Andes as in the presentday Amazon basin. Both the presence of closed forest vegetation with neotropical families and genera, and the presence of extensive marshes indicate a warm and moist tropical climate. Temperatures may have been, like in other parts of the world, warmer than they are at present, and the tropical rain forest may have extended further to the north and south. As the proper Andean mountains did not yet exist as such, the drainage of the continent must have been considerably different from the present one, and part of the central shield areas of the continent, drained towards the west, to the Pacific ocean. There seems to be even an interval that mangrove forests of Rhizophora spred over considerable extensions of the northwestern part of the present-day Amazon basin in Colombia, Ecuador and Peru, indicating direct connection with, or at least influence of the sea. During the Miocene there seems to have been already some extention of savannas or savanna-like vegetation in the northern part of South America, especially in Venezuela, as indicated locally by an increase of the percentage of pollen of Gramineae and certain other savanna plants, 
and the frequent occurrence of burnt grass cuticles in sediments. This seems to indicate that a zone with somewhat lower rainfall and several dry months is developing where it is approximately found today. This may be related to the beginning of a gradual cooling of the earth and a latitudinal shrinkage of the area of the neotropical proper central rainforest area. This "skrinkage" may also be proved for the southern hemisphere part, where the neotropical flora that occurred originally (in the Lower Tertiary) at least as far south as $38^{\circ}$, retired gradually to the North during the later Tertiary, towards its present position.

A further and most important development came with the gradual formation of low hills and mountains from the Upper Miocene on, and culminating in the final upheaval of the Andes to its present altitude during the Pliocene (VAN DER HAMMEN et al., 1973). This resulted in the total re-ordering of the drainage of the continent, now going mainly eastward and hence in the formation of the Amazon basin in its present form. It also caused the separation of rainforest areas like that of Chocó and the Magdalena valley from the Amazon basin part. A most important effect was also the localization of areas of relatively high precipitation in the westernmost Amazon near the Andean "wall", and on the Pacific side in the Chocó area.

The importance for evolution of the gradual formation under excessively dynamic circumstances of the Andes, is shown by the geographic analyses of taxonomic data of the Neotropical flora: almost half of the taxa are Amazonian centered, and half are Andean centered (GENTRY, 1982). Because of the upheaval of the Andean mountains to their present elevation, new environments were created. These montane zones were populated by adaptive evolution of neotropical flora elements from the lowlands and low mountains, and by immigration and adaptive evolution of elements from the southern subtropical to temperate zones (like Weinmannia) or from the northern subtropical temperate zones (like Quercus and Alnus). The last mentioned immigration could increase in importance with the gradual formation of the Panamanian landbridge in the Pliocene. First to cross were subtropical to warm temperate elements of the Laurasian Tertiary flora, that had migrated southward with the general cooling of the climate in the Upper Tertiary. They created the amphi-pacific disjunction of a group of elements that was present in the Tertiary Laurasian flora of North America, Europe and Asia, but migrated southward finding refuge in the tropical mountains of SE Asia and Middle and South America, while they became extinct in the area of their original distribution (like Trigonobalanus). The next to cross were more temperate elements (like Alnus, Quercus), and finally cold climate elements of open vegetation (see VAN DER HAMMEN \& CLEEF, 1983, 1986). In this way the present flora and vegetation of montane forests and páramos came into being, with an extra-neotropical generic element that increases from the lower tropical montane zone upwards to the páramo from almost nothing to about $50 \%$.

Although immigration and evolution continued to some extent during the Pleistocene, it may said that around the beginning of the Quaternary the geological-geographical and floristic-vegetational situation of the neotropical area is very similar already to the present, so that the dynamic relation of vegetation and climate in the Quaternary can be studied considering the geomorphology and flora relatively 
constant (for further information on the data mentioned in this paragraph, we may refer to e.g., VAN DER HAMMEN, 1988a, b and c).

\section{THE PLEISTOCENE HISTORY}

A continuous record of vegetational-climatic change for almost the entire Pleistocene is only known from the high plain of Bogota (e.g., VAN DER HAMMEN, 1974 and HOOGHIEMSTRA, 1984), at an elevation of $2,560 \mathrm{~m}$. Hundreds of metres of lake sediments were collected and analysed palynologically; dating was provided by fission track and Potasium-Argon analyses of intercalated volcanic ashes. The pollen diagrams show a long sequence of many glacial and interglacial periods thought to represent $2.5 \mathrm{Ma}$, that may be correlated with the sequence in deep sea sediments. The altitudinal forest limit moved between altitudes of approximately 2,000 and $3,500 \mathrm{~m}$, an amplitude of some 8 to $9^{\circ} \mathrm{C}$. Very generally speaking, interglaciais show an overall correlation to relatively low lake levels, glacials to relatively high lake levels, possibly related to higher evapotranspiration. There are, however, also correlations of some short cold intervals with low lake levels, in which case the climate should have been relatively very dry.

In the same area (Fuquene, Cordillera Oriental) the last 35,000 years could be studied in detail (VAN GEEL \& VAN DER HAMMEN, 1973); later the study was extended to approximately 120,000 years B.P. (in prep.). From these data it is evident that the last interglacial and the early glacial interstadials show relatively low lake levels. Then the lake level rises and remains relatively high with several minor fluctuations, until a very low lake level is evident, beginning around 21,000 B.P. and lasting to the beginning of the Late Glacial (approximately 13,000 B.P.). It was estimated that the rainfall in that period must have been half that of the present. Then the lake level rises fastly, to become somewhat lower between 11,000 and 10,000 B.P., and remaining relatively high (but lower than in the early Late Glacial) until the present. The climate is cold at the time during the last glacial and part of the Late Glacial, but seems to reach extremes around 21,000 B.P. Much data from the same area point to a very humid climate during the Middle Pleniglacial (approximately 60,000-30,000 B.P.) and a very dry climate during the late Upper Pleniglacial (approximately $21,000-14,000$ B.P.). It is especially evident that the maximum extension of glaciers and the accumulation of large fiuvioglacial terrace-deposits took place during this very humid Middle-Pleniglacial and partly the earlier Upper Pleniglacial $\left({ }^{14} \mathrm{C}\right.$ dates of $>50,000$ to 39,000 B.P. and locally $27,000-23,000$ B.P.) (VAN DER HAMMEN et al., 1980/81 and VAN DER HAMMEN, 1981, 1986).

If we go northeast to Venezuela, there is significant information from Lake Valencia, at $400 \mathrm{~m}$ elevation (SALGADO-LABOURIAU, 1982). The lake exists as such since 10,000 B.P. but before that (date of base of analysed section 13,000 B.P.) the lake had dried up, the climate being very dry and the region occupied by semiarid vegetation. In the Venezuelan Andes, SCHUBERT \& VELASTRO (1980) 
describe massive sandy gravelly terrace deposits between 1,100 and 3,000 m altitude, dated in the Middle Pleniglacial $(33,700-50,700$ B.P.). Still further east there are data from Guyana and Surinam (summarized in VAN DER HAMMEN, 1974). During the last glacial low sealevel (before approximately 10,000 B.P. and after $>50,000$ B.P.), dry grass savanna extended in the present-day coastal plain of these countries, indicating a climate much drier than today. In deep boreholes several levels of Pleistocene low sealevels were found, equally corresponding with the extension of grass-savanna.

From the Rupununi-savannas of the inland of Guyana, we know of the existence of a more humid savanna woodland phase, well before 7,300 B.P. and probably corresponding to the Late Glacial. Before that humid period there is a period of low lake level and extension of grass-savanna, that (according to extrapolation of the available oldest date) could very well be of Upper Pleniglacial age.

From Ecuador there are dated sections and pollen diagrams from the Galapagos islands (COLNNAUX \& SCHOFIELD, 1976), showing dry climate in the montane zone before the Holocene.

Going South through the Andes, there are some data from Bolivia (summarized in YBERT, 1988). While some lake levels are relatively low in the beginning of the Holocene, they were high in the Late Glacial (10,000-13,000 B.P. approx.), and low during several thousands of years before that time.

From Mexico there are data indicating a cold very wet climate about 40,000-25,000 B.P. and a definitely cold and dry climate between 20,000 and 12,000 B.P. The beginning of the Late Glacial is extremely wet again (HEINE, 1973).

In Rondonia, in the southern part of the Amazon basin, in the area of Capoeira and Catira, there is strong indication of a formerly drier climate (valley type and colluvial filling including fragments of eroded soils). A section from a recent sediment fill showed a dark humic layer at the bottom with pollen of wet rainforest. On top are the colluvial type sediments, that contain complete dominance of pollen of open grass-savannas. While there is no doubt about this interpretation, the age has not been established precisely, but a Young Pleistocene age seems probable. These data show beyond reasonable doubt that the rainforest in the area was once replaced temporarely by open grass savanna (VAN DER HAMMEN, 1972 and ABSY \& VAN DER HAMMEN, 1976). Recent data from the east Amazonian Carajás area confirm the existence of dry periods during the Last Glacial (see the corresponding article in these Proceedings). UU \& COLNNVAUX (1985) showed that Podocarpus grew at 1,100 m on the Eastern Andean slopes of Ecuador, but the climatic interpretation of these data (in terms of temperature or rainfall) is not yet fully clear (see below).

Besides palynological data, there is a wealth of geomorphological information relating to climatic change (e.g., summaries in BROWN, 1982 and HAFFER, 1987) in the Amazon basin and surroundings. Some data are not conclusive, but sufficient evidence remains to indicate a drier climate some period or periods in the past, especially in the late Upper Pleniglacial, around and or shortly after 20,000 B.P.. Of special interest are the occurrence of stabilized sand dunes in a very extensive area of the Lanos 
Orientales of Colombia and the Orinoco savannas of Venezuela (approx. between 5 and $10^{\circ}$ North). Often a plintitic horizon may be found below the dunes, and two ${ }^{14} \mathrm{C}$ dates of a paleosol below these dunes gave an age of resp. 11,100 and 12,300 ( \pm 500$)$ B.P. (ROA, 1979). These dates should be considered as minimun dates, as some younger humus might easily have infiltrated through the overlying sand. Anyhow, a late Pleistocene age of least part of these dunes seems very probable.

For the more central Amazonian basin near Manaus, (IRION, 1976) has published some interesting data. The proper Amazon valley must have been deeply eroded (some 100 metres) during the last period of low sealevel (ca. 20,000 B.P.), and was subsequently converted in a bay or lake until far inland, after the Late Glacial to Holocene sealevel rise, until this a bay was completely filled up and converted in várzeas (see also ABSY, 1979). Above the present level of the river plain are several extensive terrece levels, thought to represent river plain vázzea levels from earlier interglacials.

Terraces can be recognized all along the Amazon and its tributaries. Recently the Holocene sediments and lower terrace (approx. $10 \mathrm{~m}$ above the low water level of the river) in the area of the Caquetá river between Araracuara and the Cahuinari (Colombian Amazonas) are being studied stratigraphically and palynologically (ESPEJO et al., in prep.). The lower terrace consists in the lower part of gravels ( with cherts that should be of Cordilleran origin) and sands (with a hard iron oxide layer), going over upwards in sandy loam, that is capped by a reddish soil. ${ }^{14} \mathrm{C}$ dates of pieces of wood and twigs from the sandy loam were dated between 30,000 and $>50,000$ years, and are therefore of Middle Pleniglacial age. The fact that RÄSANEN et al. (1987) give a ${ }^{14} \mathrm{C}$ date of approx. 36,500 B.P. from terra firme river deposits in the Peruvian western Amazon, what should correspond to the first terrace level, seems to indicate that the Middle Pleniglacial age for the low terrace may be valid for the western Amazon in general. As the age of this terrace material is the same as that of large fluvioglacial to fluvial terraces in the Andes of Colombia, Venezuela and Peru, a relation with the extremely wet and relatively cold climate in the Andes seems indicated. The low terrace must have been "fossilized" in a period anyhow younger than 36,000 B.P. but prior to 10,000 B.P. (minimum age of the sediments in the present river valley, see below). It is tempting to suggest that this could have been in the dry and cold time of very low sealevel position, around 20,000 B.P.. Here we may also refer to DAMUTH \& FAIRBRIDGE (1970) who established the presence of arkosic sand in deepsea sediments North and West of tropical South America, in level believed to be of Upper Pleniglacial age and related to ice-age aridity.

While we are fairly certain about the lowering of temperature in the higher part of the Andean mountain (anyhow $6^{\circ}-8^{\circ} \mathrm{C}$ ), we are less sure about the lowering of temperature in the tropical lowlands. Data from deepsea sediments indicate surface tempertures of seawater in the Caribbean of only $0^{\circ}-2^{\circ} \mathrm{C}$ lower than today some 18,000 years ago. As todays surface water temperatures are in equilibrium with the average annual temperatures, this seems to suggest that temperatures at sealevel on the continent should not have been much lower than $2^{\circ} \mathrm{C}$ than today. 
Palynological data from lower parts of the mountains and from the lowlands that are interpretable in terms of temperature are very scarce or non-existent. Data from the Colombian Western Cordillera (MONSALVE, 1985) indicate that at 1,500 m altitude oak forest (Quercetum) existed during Upper Pleniglacial time $\left({ }^{14} \mathrm{C}\right.$ dated); oakforest today in the area is found between 2,500 and $3,000 \mathrm{~m}$, so a minimum lowering of vegetation zones of $1,000 \mathrm{~m}$ is suggested. These data would $\mathrm{ft}$ well in a scheme of a steeper temperature gradient during the period of dry and cold Upper Pleniglacial climate: $8^{\circ} \mathrm{C}$ lower at $2,600 \mathrm{~m}, 5,5-6^{\circ} \mathrm{C}$ lower at $1,500 \mathrm{~m}$ and $2^{\circ} \mathrm{C}$ in the tropical lowland. However, today Quercus is found sometimes at levels as low as 1,000 in the eastem Cordillera, showing that it can grow at lower levels; it is tempting then to consider these low stands as ice-age relict sites.

Another case is that of Podocarpus, UU \& COUNVAUX (1985) reported the presence of Podocarpus wood, dated about 33,500 and 26,500 B.P., at an elevation of 1,100 m on the eastern slopes of the Andes in the Ecuadorian Amazon, leading them to suggest a lowering of vegetation zones of at least 700 $\mathrm{m}$, corresponding to a lowering of temperature of at least $4,5^{\circ} \mathrm{C}$. Podocarpus, however, may grow locally much lower, and is even reported from the Pacific lowland (GENTRY, 1986), and from Iquitos in the Peruvian and from the Araracuara area in the Colomblan Amazon. From the Pacific lowland (Choco) Gentry reports several Andean montane elements like Hedyosmum, llex, Panopsis, Meliosma and Talauma and suggests that this is related to the extreme wetness of the climate. Hedyosmum pollen is also found in the Colombian Amazon (URREGO, in prep.), while some Podocarpus and Alnus pollen may regularly be found in lowland sediments. It seems therefore that the pollen spectrum from the sediments with Podocarpus wood equally cannot be considered to be conclusive for the suggested lowering of temperature. The sections reported by Lu \& Colimvaux are very interesting, as above and below the organic layer with Podocarpus wood, there are debris flow and coarse fluvial sediments, that would be of an age between older than 33,500 and younger than 26,500, and seem to correspond to the very wet phase of Middle Pleniglacial to lower Upper Pleniglacial age, mentioned earlier.

Finally we have to mention the results generated by the climate model of GATES (1976), when fed by the sea surface temperature, ice extension, albedo, etc. data for 18,000 B.P. produced by CLMAP (1976). The land temperature data generated for the Northern Andes, correspond reasonably well with those based on palynological data. The temperatures generated for the Amazon basin range from $4^{\circ}$ to $8^{\circ} \mathrm{C}$ lower than today.

From all this, the following cautious conclusions may be drawn:

- The sequence of glacial and interglaciais during the Quaternary is clearly reflected in the history of tropical montane vegetations in the Andes.

- The Middle Pleniglacial (and part of the early Upper Pleniglacial) of the last glacial period was a period of very high precipitation in the entire area.

- The Upper Pleniglacial presented a very dry period culminating between approximately 
20,000 B.P. and 14,000 B.P., causing the drying up of many lakes in the mountains, the extension of savanna at the cost of forest, probably the shrinkage of the rainforest area in its northern and southern limits, and possibly (but not yet conclusively proved or disproved) a division of the Amazonian rainforest in a northeastern and southeastern portion (compare Fig. 1) and eventually in more fragments. It seems that in this period the rivers incised their valley deeply in the formerly built lower terrace.

- Temperatures in the high mountains were $6^{\circ}-9^{\circ} \mathrm{C}$ lower than today during glacial periods. In the tropical lowlands the temperatures may have been $2^{\circ}$ to $6^{\circ} \mathrm{C}$ lower than today, but there is not yet conclusive evidence about more precise ciphers; the altitudinal temperature gradient may have been steeper (possibly related to the drier air).

\section{THE LATEGLACIAL AND HOLOCENE HISTORY}

In the tropical Andes lake levels showed a marked rise around 13,000 B.P. or somewhere in the period between 13,000 and 10,000 B.P., indicating that the climate became much wetter again after the dry phase of the Upper Pleniglacial NAN GEEL \& VAN DER HAMMEN, 1973; VAN DER HAMMEN, 1974; MARKGRAF \& BRADBURY, 1982; YBERT, 1988; etc.). In the lowlands similar evidence was found, like in the Rupununi savannas (VAN DER HAMMEN, 1974), Northern Venezuela (SALGADO-LABOURIAU, 1982) and Guatemala (LEYDEN, 1984). This important climatic changes is also well known from the African tropics, and seems to be a phenomenon of global importance (UVINGSTONE \& VAN DER HAMMEN, 1979 and FLENLEY, 1979).

The information we have on the Holocene, the last 10,000 years, is more abundant and increasingly detailed, and shows overall changes of climate and regional differentiation (MARKGRAF \& BRADBURY, 1982). From the tropical Andes we know that the beginning of the Holocene shows a gradually warming up climate, to reach annual temperatures $1^{\circ}-2^{\circ}$ higher than today in the Middle Holocene. There are clear indications of some relatively short cooler intervals e.g. around 6,000 B.P. The climate became in general somewhat cooler in the late Holocene, after c. 3,000 B.P. (VAN DER HAMMEN, 1974; MELEF, 1985; SALOMONS, 1986 and THOURET \& VAN DER HAMMEN, 1981).

In the higher and wetter zones of the Andes there is an increasing extension of Sphagnum peat bogs, especially since 5,000 to 3,000 B.P., probably the combined result of increasing humidity and soil development. Some of these bogs and their development were studied in detail by KUHRY (1988), who gives also a good compilation of the Late Glacial and Holocene changes of temperature and humidity. The relatively drier climate he suggests for the last 3,000 years however, is mainly based on the disappearance of Alnus in the highplain of Bogotá, that is certainly heavily influenced by the contemporaneous extension of indian agriculture in that area. 
Consistent and relatively detalled data on the Holocene fluctuations of humidity in Northwestern South America, come from the fluctuations of lake levels in the Andes and in the tropical savannas of the Colombian Lanos Orientales (NAN DER HAMMEN, 1974), and from the fluctuations of highwater levels of the Magdalena-Cauca-San Jorge river system (that drains a large part of the northern Andes) documented in its tropical lowland inland delta sediments (VAN DER HAMMEN, 1986) and based on many ${ }^{14} \mathrm{C}$ datings. The curve shows periods of relatively low effective rainfall in the area around 7,000 B.P., 5,500 B.P., 4,700 B.P. and 4,000 B.P. and for the late Holocene between 2,700 and 2,300 B.P. (culminating 2,500-2,300 B.P.), 2,150-2,050 B.P., 1,500/1,400-1,300 B.P. and 750-650 B.P. This last period seems to coincide with the mediaeval warm period.

It is most interesting and important that the study of a 1,500 year (annually layered) icecore from the Quelecaya Ice cap in Peru, showed dry periods between 1,380 and 1,340 B.P. and 700-650 B.P., corresponding surprisingly exact with the above-mentioned data (THOMPSON et al., 1985). The core showed also a wet period between 230 and 450 B.P., and a dry period between 230 and 90 B.P. These results, based on completely different evidence in a very differenty area, confirm the interpretation of the Magdalena data and confirm similar trends in precipitation in a large area of the western part of the continent.

COUNVAUX et al. (1976) report on a wet period in the Andes of Ecuador, between ca. 1,600 and 800 B.P., that includes the 1,300-750 B.P. wet period, but overlaps the shorter dry periods before and after; this, however, might easily be due to inaccuracies inherent to the dating method.

The later neoglacial or little ice-age is well documented in the tropical Andes by the extension of glaciers after approx. 1,400 A.D. and by their gradual retirement after approx. 1,850 A.D. until the present.

Data from the Brazilian Amazon were first presented by ABSY $(1979,1985)$, followed by a series of very interesting papers by Colinvaux and colaborators on the Amazonian part of Ecuador (COLNVAUX et al., 1985, 1988; COUNVAUX \& UU, 1987 and BUSH \& COLNNVAUX, 1988), while now a series of new sections from the Carajás area in Brazil (ABSY et al., in prep.) and from the Caquetá area in Colombia (URREGO, in prep., and ESPEJO, in prep.) have been worked out palynologically and dated, and will be published in the near future.

ABSY (1979) studied sediments from the river plain of the Amazon and afluents, that are partly lake sediments. Like in the case of the lower Magdalena valley, periods of lower river levels could be distinguished (partly by the extension and rooting of "floating meadows"). By means of a number of ${ }^{14} \mathrm{C}$ dates and interpolation a relative curve of drier and wetter periods was constructed for the last 4,000 years. This curve is not identical, but largely congruent to the Magdalena curve, suggesting an overall pattern of rainfall variations in a large part of the continent, with local differences (Fig. 2). We may expect further refinement and correction of this picture, when more data and dates from the area become available. 


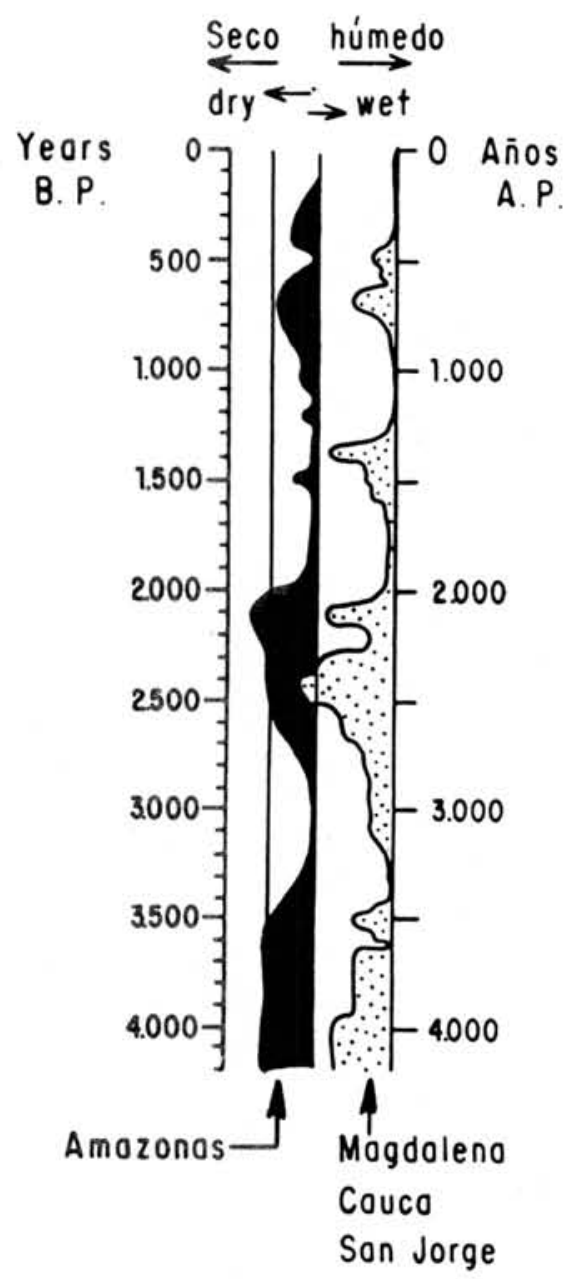

Figure 2 - Relative changes of annual effective rainfall for the Amazon (ABSY, 1979) and the Magdalena-Cauca-San Jorge watersheds (last 4,000 years), based on the relative position of river inundation levels (after VAN DER HAMMEN, 1986).

Very interesting is Absy's Costa da Terra Nova section of the upper $20 \mathrm{~m}$ of sediments of the proper Amazon valley, comprising the last 3,000 years. It starts with grey sandy clays of the in that time apparently still largely inundated valley. When the valley fills up further gradually, floating meadows and Cecropia vegetation are increasing in importance. Finally, between 1,100-700 years ago the area becomes definitely a proper vázea with seasonal inundation only and the formation of gley soils.

Inundation of the Amazon valley and afluents, until deeply inland, must have taken place with the Increasing rainfall and the rising sealevel since the Late Glacial. New data from the Caquetá river (below Araracuara, Colombia) show inundation of this river valley at the beginning of the Holocene, and the gradual filling of the lake(s) with light grey clays, going over from ca. 6,000 B.P. on, in marshes and várzea, finally dominating seasonally inundated vázea (URREGO, in prep. and ESPEJO, in prep.). Alternation of peats and clays seem to indicate alternation of periods of higher and lower river levels, that are being dated by ${ }^{14} \mathrm{C}$ analyses. 
COLNVAUX et al. (1988) reported on some pollen diagramas of old river channel lakes from the western Amazon basin in Ecuador, indicating general flooding during the approx. 1,300-800 B.P. interval and post-flooding gradually changing forest vegetations. A deep core from a lake independent of river inundation (lake Kupala, a former crater at $700 \mathrm{~m}$ elevation) yielded a history of 5,200 years (UU \& COLNNVAUX, 1988). The interpretation of sediments and pollen diagrams indicate a drier episode around 4,000 B.P., and possibly a wetter episode in the $1,300-800$ years B.P. period. The continuous abundant presence of Cecropia indicates continuous disturbance in the forest, that may be related to storms, high rainfall and steep crater-rim slopes. Another crater lake in the Amazonian part of Ecuador (Ayauchi reveals 7,000 years of steady state forest history, but the presence of a weathered gyttja indicates a dry period of low lake levels between 4,280-3,200 B.P. (BUSH \& COUNVAUX, 1988).

SERVANT et al. (1981) showed that the forest disappeared at least locally and dunes were formed in the area of Santa Cruz-de la Sierra in the Bolivian Amazon (alt.ca. $500 \mathrm{~m}, 18^{\circ}$ south), between 7,000 and 5,000 B.P. and 3,400-1,400 B.P. In the Rio Doce basin in Atlantic Brazil (18 ${ }^{\circ}-20^{\circ}$ lat.S), today covered by dense tropical forests, geomorphological studies supported by ${ }^{14} \mathrm{C}$ dates showed earlier Holocene aridity, culminating 8,500 B.P. (SERVANT et al., 1989). The authors suggest that this drier climate in the southern tropical area of South America could be caused by a displacement towards the North of the zone of intertropical convergency.

Charcoal in soils is widespread in the Amazon basin (SOUBIES, 1979, 1980 and SALDARRIAGA \& WEST, 1986), dated between approx. 6,000 and 3,000 B.P. (and locally somewhat older and younger), and could be related to drier climate episodes and/or to human influence.

From the above information on the Late Glacial and Holocene we may draw the following cautious conclusions:

- The beginning of the Late Glacial (ca. 13,000 B.P. shows a rising temperature, from glacial to interglacial temperatures, but presents several phases of higher and lower temperatures. Middle Holocene temperatures reach values some $1^{\circ}-2^{\circ} \mathrm{C}$ higher than today; the last 3,000 years were somewhat cooler again (data from the tropical Andes only).

- The Late glacial and Holocene climate in general is considerably wetter than the preceding dry Upper Pleniglacial. At the beginning of this period, partly combined with a rising sealevel it led to flooding of lowland river valleys, that then gradually were filled up with sediments.

- For the Holocene (and especially for the last ca. 5,000 yeas) we konw a sequence of drier and wetter periods, that had a considerable influence on the lowland valley vegetations, by successive high water levels (flooding) and relatively low water levels (extension of marsh-vegetations and vázea). There seems to be an overall pattern of change in rainfall in a large part of the continent, with local variations. This picture needs further confirmation and more detail. Holocene phases of pronounced dryness, resulting in dune formation or slope erosion are known from the rain forest $18^{\circ}-20^{\circ}$ lat. South. 


\section{DISCUSSION AND CONCLUSIONS}

From the above it will be clear, that strong changes of temperature and rainfall affected tropical South America during the last few millions of years, known in more detail from the last glacialinterglacial cycle. Very humid and cooler climate (or a sequence of very humid climates, alternating with somewhat less humid periods) occurred in the period between $>50,000$ and ca.25,000/30,000 B.P. A cold and very dry climate occurred in the period of ca.21,000-c. 14,000 B.P. Between 13,000 and 10,000 the climate became warmer and more humid, and from 10,000 to present (the Holocene), the climate is more like the present, but there are still changes of temperature and especially of rainfall. Changes of temperatures were eatablished quantitatively beyond doubt in the tropical Andes, but ciphers for the tropical lowland are still uncertain.

The climatic changes had a very profound effect on the vegetation, both in the mountains and in the lowlands. There is no doubt that rainforest disappeared in some areas during certain climatic intervals. This was relatively well eatablished for e.g. the southernmost part of the Amazon basin. In the northern savanna area of South America large areas were changed in sand deserts. However, palaeoecological data on the possible replacement of forest by savanna or other dry types of vegetation are still lacking for much of the Amazon basin.

Until now we have purposely not discussed the forest-refugia theory, first proposed by HAFFER (1969). Later, the theory was further supported by taxonomic-biogeographical data for different groups of plants and animals, or criticized (see Fig. 3 and many articles in PRANCE, 1982). The theory is principally based on the existence of centres of endemism in tropical South America and especially within the Amazon basin, and indications on climatic change that might have led to the local replacement of rainforest by drier types of vegetation, leaving isolated rain forest refuges. An extensive study that assembles much of the existing data, is that of BROWN (1982). In many of these articles also a critical atitude to the theory may be found and recently several authors have expressed their doubts that forest refugia were the only cause of inter-Amazonian centres of endemism and diversity (e.g., CAMPBEL \& FRAGLEY, 1984; RASÄNEN et al., 1987; COUNVAUX et al., 1988, etc.). Differences in environmental circumstances like rainfall (Fig. 1) and soil within the Amazon basin, high river dynamic causing continuous disturbance over a long period of time (especially in the western Amazon) and the very broad rivers as possible effective barriers, are mentioned as possible alternative factors to be taken into account to explain the centres of endemism and high diversity. It seems probable that all these factors have to be taken into account, together with possible forest refuges. What we need now urgently is palaeoecological data from all over the Amazon basin to reconstruct the past on the basis of historical data. Until that time, the discussion will remain necessarily very theoretical.

From the point of view of those working with general circulation models and recent 


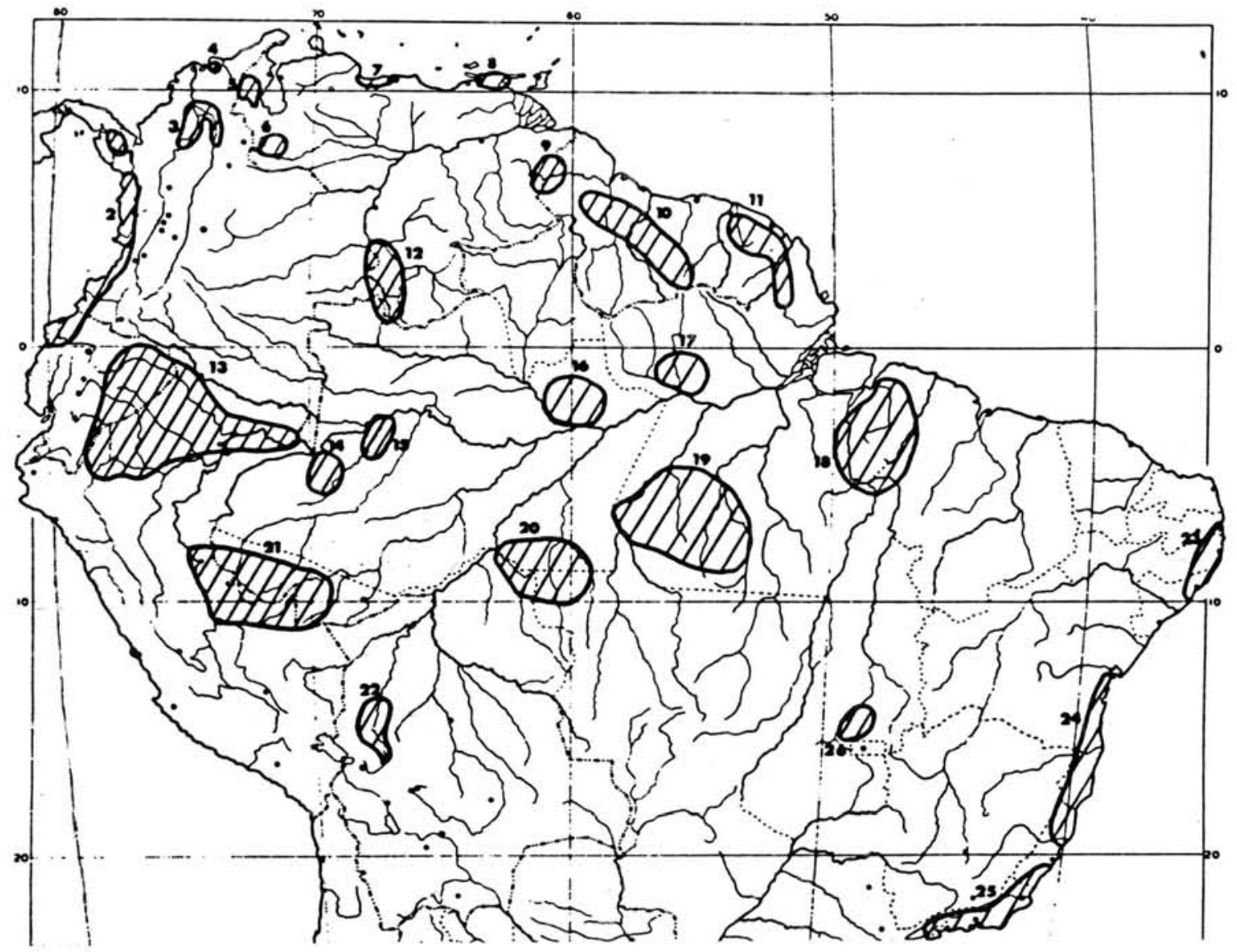

Figure 3 - An example of possible forest refuges, based on the distribution of woody Angiosperm families, as proposed by Prance (after PRANCE, 1982).

climatic change, in order to predict what we may expect to happen in the near future as a result of both "natural" and human induced climatic change, the extension back in time for the last hundreds or thousands of years of a quantitative climatic record is most urgent. Modern palaeoecology can in principle provide these data, by detailed analyses of especially organic sediments and lake deposits: palynological, macrobotanical, chemical, stable isotopes etc. The use of refined dating techniques (e.g., with the help of pollen density in combination with isotopic dating (MIDDELDORP, 1982), is essential for that purpose, and certain methods to obtain temperature values (like Deuterium analyses; DUPONT, 1986) have to be developed further. Time series analyses of the results obtained (WIJMSTRA et al., 1984) may reveal the possible periodic character of certain short-term climatic changes. This effort will probably now be intensified worldwide in the large international project on climatic change, the Geosphere-Biosphere program. 


\section{REFERENCES}

ABSY, M.L. (1979) A palynological study of Holocene sediments in the Amazon Basin. Diss.Univ. of Amsterdam.

ABSY, M.L. (1985) Palynology of Amazônia: the history of the forests as revealed by the palynological record. In: PRNCE, G.T. \& LOVEJOY, T.E. (eds.) Amazônia. Oxford, Pergamon Press. p.72-82.

ABSY, M.L \& VAN DER HAMMEN, T. (1976) Some palaeoecological data from Rondônia, southern part of the Amazon basin. Acta Amazonia, 6:293-299.

BRADBURY, J.P.; LEYDEN, B.; SALGADO-LABOURIAU, M.; LEWIS, W.M.; SCHUBERT, C.; BRUFORD, M.W.; FREY, D.G.; WHITEHEAD, D.R.; WEIBEZAHN, F.H. (1981) Late Quaternary environmental history of Lake Valencia, Venezuela. Science, 214(4527):1299-1305.

BROWN, K.S. (1982) Paleoecology and regional patterns of evolution in Neotropical forest butterflies. In: PRANCE, G.T. (ed.). Biological diversification in the tropics. New York, Columbia University Press. p.255-308.

BUSH, M.B. \& COLNVAUX, P.A. (1988) A Holocene palynologic history of lake Ayauchí, Ecuador; an Amazonian crater lake.

CAMPBELL, K.E. \& FRAILEY, C.D. (1984) Holocene flooding and species diversity in southwestern Amazônia. Quaternary Research, 21:369-375.

CLMAP Project Members (1976) The surface of the ice-age earth. Science, 191(4232):1131-1137.

COLINVAUX, P.A. (1987) Amazon diversity in light of the palaeoecological record. Quaternary Science Reviews, 6(2): 93-114.

COLINVAUX, P.A. \& SCHOFIELD, E.K. (1976) Historical ecology in the Galapagos Islands. I. A Holocene pollen record from El Junco Lake, Isla San Cristobal. Journal Ecology, 64:989-1012.

COLINVAUX, P.A.; MILER. M.C.; UU, L; STEINETZ-KAUMAN, M.M.; FROST, I. (1985) Discovery of permanent Amazon lakes and hydraulic disturbance in the upper Amazon basin. Nature, 313:42-45. 
COLNVAUX, P.A. \& UU, K. (1987) The Late Quaternary climate of the western Amazon basin. In: BERGER, W. \& LABEGRIE, L (eds.) Abrupt climatic change: evidence and implications. Dordrecht, D. Reidel. p.113-122.

COLNVAUX, P.A.; FROST, M.; FROST, I.; UU, K.; STEINETZ-KAUMAN, M. (1988) Three pollen diagrams of forest disturbance in the western Amazon basin. Review Palaeobotany and Palynology, 55(1-3):7381.

COUNVAUX, P.A.; OLSON, K.; UU, K. (1988) Late-glacial and Holocene pollen diagrams from two endorheic lakes of the Inter-Andean Plateau of Ecuador. Review of Palaeobotany and Palynology, 55(1-3):83-99.

DAMUTH, J.E. \& FAIRBRIDGE, R.W. (1970) Equatorial Atlantic deep-sea arkosic sands and ice-age aridity in tropical South America. Geological Society America Bulletin, 81:189-206.

DUPONT, LM. (1986) Temperature and rainfall variation in the Holocene based on comparative palaeoecology and isotope geology of a hummock and a hollow. Review of Palaeobotany and Palynology, 48(1-3):71-159.

FLENLEY, J.R. (1979) The equatorial rainforest: a geological history. London Butterworths. 162p.

GATES, W.L (1976) Modeling the ice-age climate. Science, 191:1138-1144.

GENTRY, A.H. (1982) Neotopical floristic diversity: phytogeographical connections between Central and South America; Pleistocene climatic fluctuations, or an accident of the Andean Orogeny. Annals of Missouri Botanical Garden, 69 (3):557-593.

GENTRY, A.H. (1986) Species richness and floristic composition of Chocó region plant communities. Caldasia, 15:71-91.

HAFFER, J. (1969) Speciation in Amazonian forest birds. Science, 165:131-137.

HAFFER, J. (1987) Quaternary history of tropical America. In: WHITMORE, T.C. \& PRANCE, G.T. (eds.) Biogeography and Quaternary history in tropical America. Clarendon Press, Oxford. p.1-18. 
HEINE, K. (1973) Variaciones más importantes del clima durante los últimos 40.000 años en Mexico. Comunicaciones, 7:51-56.

HOOGHIEMSTRA, H. (1984) Vegetation and climatic history of the High Plain of Bogota Colombia: a continuous record of the last 3,5 million years. In: CRAMER, J. (ed.) Dissertationes Botanicae. Berlin, Gebrüder Borntraeger. p.1-214. (Diss. Bot. 79).

IRION, G. (1976) Die Entwicklung des Zentral- und Oberamazonischen Tieflands im Spăt-Pleistozän und im Holozän. Amazoniana, 6(1):67-79.

KUHRY, P. (1988) Palaeobotanical-palaeoecological studies on tropical high Andean peatbog sections (Cordillera Oriental, Colombia). In: CRAMER, J. (ed.) Dissertationes Botanicae. Berlin, Gebrüder Borntraeger. p.1-214. (Diss. Bot).

LEYDEN, B.W. (1984) Guatemalan forest synthesis after Pleistocene aridity. Proceedings of the National Academy of Sciences of the United States of America, 81:4856-4859.

UU, K. \& COLNVAUX, A. (1985) Forest changes in the Amazon basin during the last glacial maximum. Nature, 318:556-557.

UU, K. \& COLINVAUX, A. (1988) A 5,200 year history of Amazon rain forest. Journal of Biogeography, 15:231-245.

LIVINGSTONE, D.A. \& VAN DER HAMMEN, T. (1979) Palaeoegeography and Palaeoclimatology. In: Tropical forest ecosystems: a state-of-knowledge report prepared by Unesco Unep/Fao Paris, p.61-90.

MARKGRAF, V. \& BRADBURY, J.P. (1982) Holocene climatic history of South America. In: MANGERUD, J.; BIRKS, H.J.B.; JÄGER, K.D. (eds.) Chronostratigraphic subdivision of the Holocene. p.40-45. (Striae, 16).

MELIEF, B.M. (1985) Late Quaternary Palaeoecology of the Parque Nacional Natural los Nevados (Cordillera Central) and Sumapaz (Cordillera Oriental), area Colombia. Thesis Univ. of Amsterdam. $162 p$.

MIDDELDORP, A.A. (1982) Pollen concentration as a basis for indirect dating and quantifying net organic 
and fungal production in a peatbog ecosystem. Review Palaeobotany and Palynology, 37:225-282.

MONSALVE, J.G. (1985) A pollen core from Hacienda Lucitania. Pro Calima, 4, Basel.

PRANCE, G.T. (1982) Biological diversification in the tropics. New York, Columbia University Press. 714p.

RÄSÄNEN, M.E.; SALO, J.S.; KALOLA, R.J. (1987) Fluvial perturbance in the western Amazon Basin: regulation by long- term sub-andean tectonics. Science, 238:1398-1401.

ROA MORALES, P. (1979) Estudio de los médanos de los Lanos centrales de Venezuela: evidencias de un clima desértica. Acta Biologica Venezuelica, 10(1):19-49.

SALDARRIAGA, J.G. \& WEST, D.C. (1986) Holocene fires in the northern Amazon Basin. Quaternary Research, 26:358-366.

SALGADO-LABOURIAU, M.L (1982) Climatic change at the Pleistocene-Holocene boundary. In: PRANCE, G.T. (ed.) Biological diversification in the tropics. New York, Columbia University Press. p. 74-77.

SALOMONS, J.B. (1986) Palaeoecology of volcanic soils in the Colombian Central Cordillera (Parque Nacional Natural de los Nevados). In: CRAMER, J. (ed.) Dissertationes Botanicae Berlin, Gebrüder Borntraeger. 212p.

SCHUBERT, C. \& VELASTRO, S. (1980) Quaternary Esnujaque Formation: preliminary alluvial chronology in a tropical mountain range. Zeitschrift der Deutschen Geologischen Gesellschaft, 131:927-947.

SERVANT, M.; FONTES, J.C.; RIEU, M.; SALEGE, J.F. (1981) Phases climatiques arides holocènes dans le sud-ouest de l'Amazonie (Bolivie). Comptes Rendus Academie Sciences, Ser.2, (292):1295-1297.

SERVANT, M.; FOURNIER, M.; SOUBIES, F.; SUGUIO, K.; TURCQ, B. (1989) Sécheresse holocène au Brésil (18-20 $0^{\circ}$ latitude sud). Implications paléometéorologiques. Comptes Rendus Academie Sciences, Ser.2, (309):153-156.

SOUBIES, F. (1980) Existence d'une phase sèche en Amazonie Brésiliènne dateé par la présence de 
charbons dans les sols (6000-3000 ans B.P.). Cahiers ORSTOM. Série Géologie, 11(1): 133-148.

THOMPSON, L.G.; MOSLY-THOMPSON, E.; BOLZAN, J.F.; KOEI, B.R. (1985) A 1,500 year record of tropical precipitation in ice-cores from the Quelecaya Ice cap, Peru. Science, 229(4717): 971-973.

THOURET J.C. \& VAN DER HAMMEN, T. (1981) Una secuencia holocénica y tardiglacial en la Cordillera Central de Colombia. Revista CIAF, 6:(1-3):609-634.

VAN DER HAMMEN, T. (1972) Changes in vegetation and climate in the Amazon Basin and surrounding areas during the Pleistocene. Geologie en Mijnbouw, 51(6):641-643.

VAN DER HAMMEN, T. (1974) The Pleistocene changes of vegetation and climate in tropical South America. Journal Biogeography, 1:3-26.

VAN DER HAMMEN, T. (1981) Environmental changes in the Northern Andes and the extinction of Mastodon. Geologie en Mijnbouw, 60(3):369-372.

VAN DER HAMMEN, T. (1986) Fluctuaciones holocénicas del nivel de inundaciones en la Cuenca del Bajo Magdalena-Cauca-San Jorge (Colombia). Geología Norandina, 10:11-18.

VAN DER HAMMEN, T. (1986) La Sabana de Bogotá y su lago en el Pleniglacial Medio. Caldasia, 15(7175):249-262.

VAN DER HAMMEN, T. (1988) History of the montane forests of the Northern Andes. Springer Verlag, Vienna.

VAN DER HAMMEN, T. (1988) The tropical flora in historical perspective, Taxon.

VAN DER HAMMEN, T.; WERNER, J.H.; VAN DOMMELEN, H. (1973) Palynological record of the upheaval of the Northern Andes: a study of the Pliocene and Lower Quaternary of the Colombian Eastern Cordillera and the early evolution of its high andean biota. Palaeogeography, Palaeoclimatology, Palaeoecology, 16(1/2):1-122.

VAN DER HAMMEN, T.; BARELDS, J.; DE JONG, H.; DE VEER, A.A. (1981) Glacial sequence and environmental history in the Sierra Nevada del Cocuy (Colombia). Palaeogeography, 
Palaeoclimatology, Palaeoecology, 32:247-340.

VAN DER HAMMEN, T. \& CLEEF, A.M. (1983) Trigonobalanus and the tropical amphipacific element in the North Andean forest. Journal of Biogeography, 10:437-440.

VAN DER HAMMEN, T. \& RUIZ, P.M. (1984) La Cordillera Central Colombiana Transecto Parque los Nevados (Introducción y datos iniciales). In: CRAMER, J. (ed.) Studies on tropical Andean ecosystems. 2.ed. Berlin, Gebrüder, Borntraeger. v.1.

VAN DER HAMMEN, T. \& RUIZ, P.M. (1984) Sierra Nevada de Santa Marta (Colombia) transecto BuritacaLa Cumbre. In: CRAMER, J. (ed.) Studies on tropical Andean ecosystems. 2.ed. Berlin, Gebrüder Borntraeger. v.2.

VAN DER HAMMEN, T. \& CLEEF, A.M. (1986) Development of the high Andean paramo flora and vegetation. In: VEUILLEUMIER, F. \& MONASTERIO, M. (eds.) High altitude tropical biogeography. Oxford, University Press. p.153-200.

VAN GEEL, B. \& VAN DER HAMMEN, T. (1973) Upper Quaternary vegetational and climatic sequence of the Fúquence area (Eastern Cordillera, Colombia). Palaeogeography, Palaeoclimatology, Palaeoecology, 14:9-92.

WIJMSTRA, T.A ; HOEKSTRA, S.; DE VRIES, B.J.; VAN DER HAMMEN, T. (1984) A preliminary study of periodicities in percentage curves dated by pollen density. Acta Botanica Neerlandica, 33(4):547-557.

YBERT, J.P. (1988) Apports de la palynologie à la connaissance de l'historie du lac Titicaca (Bolivie-Pérou) au cours du Quaternaire récent. Travaux de la Section Scientifique et Technique, 25:139-150. 